\title{
LIBERALISASI ISLAM DI INDONESIA PERSPEKTIF KONTEKTUAL
}

\author{
Jejen Kurnia Azri \\ Program Magister Religious Studies pascasarjana UIN Sunan gunung Djati Bandung \\ Jl.A.H Nasution 105 Cibiru, Bandung 40614.Indonesia \\ E-mail: Azri_Jejen@yahoo.com
}

\begin{abstract}
This study tries to analyze Islamic Liberal thought in Indonesia context. Islamic Liberal in this study analyzed of its genealogy, a frame of reference and contextuality of issue on Indonesia, by using two approaches were complementary. The first, by using positivistic approach to objective explanation an Islamic Liberal thought. The second, by using verstehen approach to interpret the meaning of Islamic Liberal thought on its context. It $\mathrm{I}$ s found that in Islamic Liberal thought there are many problems that can make social destruction, because it goes beyond text, seeking that which is represented or revealed by language, then it ${ }^{\text {te }} \mathrm{s}$ miss social meaning which based on the text. Islamic Liberal thought didn"e really destructive in it"s thought, but in its implementation which is not true to context. In the middle east context, Islamic Liberal thought struggles to liberate the spirit of Islam from corrupt power isolation. But isn"t like that on Indonesia, because the political majority in Indonesia isn"et majority religious.
\end{abstract}

Keywords

Freedom of Thought, Idea of Progres, Rights of Minority

\begin{abstract}
Abstrak
Penelitian ini mencoba menganalisis pemikiran Islam liberal di Indonesia. Liberal Islam dalam penelitian ini menganalisis silsilahnya, kerangka acuan dan kontekstualitas isu di Indonesia, dengan menggunakan dua pendekatan yang saling melengkapi. Yang pertama, dengan menggunakan pendekatan positivistik untuk penjelasan obyektif pemikiran Liberal Islam. Yang kedua, dengan menggunakan pendekatan verstehen untuk menafsirkan makna pemikiran Liberal Islam dalam konteksnya. Ditemukan bahwa dalam pemikiran Liberal Islam ada banyak masalah yang dapat membuat kerusakan sosial, karena melampaui teks, mencari apa yang diwakili atau diungkapkan oleh bahasa, maka itu adalah kehilangan makna sosial yang didasarkan pada teks. Pemikiran Liberal Islam tidak benarbenar merusak pemikirannya, namun dalam implementasinya yang tidak sesuai dengan konteksnya. Dalam konteks Timur Tengah, pemikiran Liberal Islam berjuang untuk membebaskan semangat Islam dari isolasi kekuasaan yang korup. Tapi tidak seperti itu di Indonesia, karena mayoritas politik di Indonesia bukan mayoritas beragama.
\end{abstract}

Kata kunci

Kebebasan Berpikir, Ide Progres, Hak Minoritas

\section{A. PENDAHULUAN}

Sejak awal, gagasan Islam Liberal di Indonesia berasal dari intelektual yang berlatar belakang pendidikan IAIN (sekarang UIN). Sebut saja Cak-Nur (Nurcholish Madjid), Harun Nasution, Mukti Ali, Munawir Sadjali dan Djohan Effendi. ${ }^{1}$ Mereka adalah "orang

1 Kecenderungan Pemikiran Islam para tokoh ini pada Liberalisme terbaca sangat jelas dalam karyakarya seperti, Fachry Ali \& Bachtiar Effendi, Merambah Jalan Baru Islam: Rekonstruksi Pemikiran Islam Indonesia Masa Orde Baru (1986); M.Syafie ${ }^{\mathrm{i}}$ Anwar, Pemikiran dan Aksi Islam Indonesia: Sebuah dalam" IAIN yang telah berjasa menyemaikan benih pemikiran Islam Liberal di Indonesia sejak dekade 1970-an. Saat itu istilah Islam Liberal belum sepopuler sekarang, namun substansi dan metodologi pemikiran mereka jelas liberal. Selanjutnya, barulah para pemain non-IAIN, baik atas nama pribadi maupun dari Ormas dan LSM ikut meramaikan gagasan

Kajian Politik tentang Cendekiawan Muslim Orde Baru (1995); Dedy Djamaluddin Malik \& Idi Subandi Ibrahim, Zaman Baru Islam Indonesia: Pemikiran dan Aksi Politik (1998); dan, Greg Barton, Gagasan Islam Liberal di Indonesia: Pemikiran Neo-Modernisme Nurcholish Madjid, Djohan Effendi, Ahmad Wahib dan Abdurrahman Wahid (1999) 
Islam Liberal di Indonesia; ada Gus-Dur (Abdurrahman Wahid), Kuntowijoyo, Dawam Rahardjo, Ulil Abshar Abdalla dan lain-lain. ${ }^{2}$ Sehingga, suka atau tidak, sebagian orang UIN dicitrakan oleh masyarakat sebagai agen Islam Liberal di Indonesia.

Maka, bagi orang UIN ketika membincang Islam Liberal, lebih arif jika mendekatinya dari dua posisi dan dua pendekatan. Pertama, pada satu sisi posisi orang UIN adalah ilmuwan yang harus objektif dalam mengamati subjek Islam Liberal. Karena itu pendekatannya harus ilmiah-positivistik; Kedua, posisi orang UIN di mata masyarakat tidak mudah dilepaskan dari citra sebagai "orangdalam" yang membidani Islam Liberal. Karena itu pendekatan yang kedua ini niscaya harus verstehen (introspeksi dan mawas diri). Kalau kita mau pakai dua pendekatan ini, yakni pendekatan ilmiah-positivistik dan verstehen secara komplementer, mudah-mudahan kita bisa mengamati Islam Liberal secara lebih murni dan konsekuen.

Tapi, jika kita kesulitan untuk pakai dua pendekatan itu sekaligus, maka pilihlah salah satu pendekatan yang "berlawanan" dengan kecenderungan "selera" kita. Mengapa begitu? Karena setiap manusia pasti memiliki "sisigelap" (kecenderungan buruk) yang secara laten tersimpan dalam dirinya. Maka, butuh "nyali besar" untuk berani rendah hati menerima kritik dari luar perspektif kita, demi meminimalisir aktualitas "sisi gelap" kita masing-masing. Jadi, bagi orang UIN yang "cinta-mati" Islam Liberal, dalam mengamati Islam Liberal pilihlah pendekatan ilmiahpositivistik. Dan bagi orang UIN yang "cintamati Islam Fundamental", pilihlah pendekatan verstehen saat mengamati Islam Liberal.

\footnotetext{
${ }^{2}$ Khusus untuk Ulil Abshar Abdalla, gagasan Islam Liberalnya meledak menjadi polemik yang kontroversial sejak artikelnya dimuat di Harian Kompas, Senin 18 November 2002 dengan judul: Menyegarkan Kembali Pemahaman Islam; Lihat juga, Luthfi Assyaukanie (ed.), Wajah Liberal Islam Indonesia (2002); Ulil Abshar Abdalla, Menjadi Muslim Liberal (2005); dan Ulil Abshar Abdalla, Menyegarkan Kembali Pemikiran Islam: Bunga Rampai Surat-Surat Tersiar (2007).
}

\section{B. HASIL DAN PEMBAHASAN}

\section{Asal Usul Istilah Islam Liberal}

Apa itu Islam Liberal? Pertanyaan ini harus kita kupas tuntas dari mata-airnya. Adalah Leonard Binder dan Fazlur Rahman. Keduanya adalah Guru Besar pada Universitas Chicago; Binder adalah profesor pada Fakultas Ilmu Politik, adapun Rahman adalah profesor dalam bidang Filsafat dan Pemikiran Islam. Mereka sepakat melakukan sebuah proyek penelitian yang berpusat di Universitas Chicago dan diberi judul: "Islam dan Perubahan Sosial". Proyek penelitian tersebut berlangsung 5 tahun (1974-1978) dengan mendapat dukungan dana yang tidak kecil dari Ford Foundation. ${ }^{3}$ Hasilnya, proyek penelitian ini menemukan dan mengembangkan wacana baru yang muncul di Dunia Islam kontemporer, yakni Islam Liberal. Temuan tersebut selanjutnya dipublikasikan luas melalui sebuah buku yang ditulis sendiri oleh Binder dan diterbitkan oleh Universitas Chicago Press pada tahun 1988 dengan judul "Islamic Liberalism". Dari tulisan Binder inilah, pemikiran "Islam Liberal" selanjutnya menjadi wacana yang mendunia.

Binder mengungkapkan, ciri pokok dari Islam Liberal adalah upaya untuk menangkap esensi terdalam dari wahyu; artinya, makna wahyu ada di luar lahiriah dari kata-kata yang tertulis pada kitab suci. Islam Liberal, bagi Binder, bersedia meninggalkan makna lahir dari teks untuk menemukan makna terdalam dari konteks historis pada ruang dan waktu ketika wahyu itu turun. Lebih jelasnya, Binder menuliskan sebagai berikut:

For Islamic Liberals, the language of the Qurean is coordinate with the essence of revelation, but the content and the meaning of revelation is not essentially verbal. Since the words of the Qur'an do not exhaust the meaning of revelation, there is a need for an effort at understanding which is based on the words, but which goes beyond them,

\footnotetext{
3 Periksa Pengantar yang ditulis oleh Leonard Binder dalam bukunya sendiri, Binder, Leonard (a), Islamic Liberalism, (Universitas of Chicago Press, 1988), Terj. Imam Muttaqin, (Yogyakarta: Pustaka Pelajar, 2001), hal: v-vi
} 
seeking that which is represented or revealed by language. ${ }^{4}$

Kata Binder, "Bagi Islam Liberal, bahasa al-Qur"an sejajar dengan esensi pewahyuan, tetapi kandungan dan makna pewahyuan pada dasarnya tidak bersifat verbal (terbatas pada teks). Karena kata-kata (teks) dalam al-Qurean tidak mengungkapkan langsung makna pewahyuan, maka diperlukan adanya upaya pemahaman yang berdasar pada teks, tetapi bergerak keluar teks (menuju konteks), untuk mengkaji lebih dalam apa yang sesungguhnya hadir dan diwahyukan melalui bahasa". Inilah watak metodologis dari Islam Liberal. Lalu apa sesungguhnya yang dicari oleh Islam Liberal dengan meninggalkan makna lahiriah teks al-Qurean (juga Hadits) menuju makna konteksnya itu? Fazlur Rahman menyebutnya sebagai, "the embodiment of the fundamental human values of freedom and responsibility" (untuk suatu perwujudan cita-cita kemanusiaan fundamental mengenai kebebasan dan tanggung jawab). ${ }^{5}$

Dalam konteks Indonesia, oleh Greg Barton, watak Islam Liberal itu dinisbatkan pada wacana Neo-Modernisme Islam-nya Fazlur Rahman, yang ditemui pada pemikiran empat tokoh: Cak-Nur, Gus-Dur, Djohan Effendi dan Ahmad Wahib. Menurut Barton, wacana Neo-Modernisme Islam yang ditampilkan oleh keempat tokoh itu bersifat moderat, liberal dan progresif, yang secara terbuka dan dialogis menempatkan diri sebagai respon terhadap modernitas. ${ }^{6}$ Berbeda dari wacana Modernisme Islam yang masih memiliki obsesi untuk menyatukan agama dan negara, dengan menerapkan syarie at Islam sebagai ideologi negara dalam bingkai nation state; wacana Neo-Modernisme Islam mendukung ide pemisahan agama dan negara. NeoModernisme Islam cendrung mengambil

\footnotetext{
${ }^{4}$ Binder, Leonard (b), Islamic Liberalism, (Universitas of Chicago Press, 1988), hal. 5.

5 Rahman, Fazlur, Islam, (Chicago \& London: The University of Chicago Press, 1979) hlm. 39. Cita-cita inilah yang menjadi acuan Islam Liberal, seperti dituliskan dalam, Ulil Abshar Abdalla, op.cit., hal 196.

${ }^{6}$ Greg Barton, Gagasan Islam Liberal di Indonesia: Pemikiran Neo-Modernisme Nurcholish Madjid, Djohan Effendi, Ahmad Wahib dan Abdurrahman Wahid (Jakarta: Paramadina1999) hlm. 9
}

posisi untuk menempatkan Islam sebagai nilai maupun etika yang berlandaskan atas keadilan, kesetaraan, demokrasi dan penghargaan terhadap kemanusiaan sebagai suatu landasan kultural dalam kehidupan bermasyarakat maupun berpolitik. ${ }^{7}$

Jadi, dari kajian Binder, Rahman dan Barton itu, setidaknya kita bisa sepakat untuk satu definisi yang akan kita gunakan di sini.

\section{Genealogi Islam Liberal di Indonesia}

Setiap gerakan pemikiran keagamaan kontemporer lazimnya selalu muncul sebagai respon terhadap arus modernisasi yang berdampak liberasi dalam segala aspek kehidupan, meskipun respon itu bisa beragam cara, berupa penerimaan, penolakan ataupun negosiasi dan kompromi. Demikian halnya dengan gerakan pemikiran Islam. Charles Kurzman menuliskan, ${ }^{8}$ sejak dua abad lalu telah ada 3 tradisi interpretasi sosio-religius yang berkembang di seluruh wilayah Islam secara berturut-turut, yakni Islam Adat, Islam Revivalis dan Islam Liberal. Kritisi atas Islam Adat melahirkan Islam Revivalis; kritisi atas Islam Revivalis dan Islam Adat melahirkan Islam Liberal. Sementara Fazlur Rahman mengungkapkan, ${ }^{9}$ sejarah gerakan pembaruan Islam dibangun atas empat fase penting: Revivalisme, Modernisme, Neo-Revivalisme dan Neo-Modernisme.

Dalam konteks Indonesia, Islam Liberal dapat dibedakan atas 2 madzhab, yakni: NeoModernisme dan Post-Tradisionalisme. Selanjutnya, Neo-Modernisme itu terbagi lagi atas yang Pro-Modernisasi dan yang ProTransformasi. ${ }^{10}$

Islam Liberal muncul sebagai produk dialektika antara Islam, modernisme dan tradisi lokal. Gagasan Cak-Nur: Islam, Kemo-

\footnotetext{
${ }^{7}$ Ibid., hal. 5.

${ }^{8}$ Lihat, Kurzman, Charles, Liberal Islam: A Sourcebook (New York: Oxford University Press, Inc., 1998), Terj. Bahrul Ulum \& Heri Junaidi, (Jakarta: Paramadina, 2003), hal. xv

${ }^{9}$ Fazlur Rahman, sebagai mana dikutip dalam, Barton, op.cit., hal. 9.

${ }^{10}$ Periksa, Airlangga Pribadi \& M. Yudhie R. Haryono, Post Islam Liberal, (2002) hal. 210-247
} 
dernan dan Ke-Indonesiaan, jelas sekali mengkonstruksikan tentang itu.

Gagasan Islam Liberal di Indonesia berkembang dalam dua madzhab:

Neo-Modernisme Islam Neo-Modernisme Islam di Indonesia dirintis oleh Nurcholish Madjid dengan mengacu pada pemikiran NeoModernisme Islam Fazlur Rahman, pemikir Islam asal Pakistan. ${ }^{11}$ Tujuan utama NeoModernisme Islam adalah menggagas agar umat Islam mampu menghadapi tantangan peradaban modern, dengan memberikan jawaban-jawaban otentik yang berdasarkan pada khazanah intelektual klasik Islam dan pemahaman yang kuat terhadap modernitas. ${ }^{12}$ Rahman dalam merumuskan metodologi ijtihad-nya banyak mengutip Abu-Yusuf, seorang qadhi pada masa khalifah al-Mahdi, al-Hadi dan al-Rasyid dalam Daulah Abbasiyah. Abu Yusuf sendiri adalah murid dari Abu Hanifah, Imam madzhab Hanafi. ${ }^{13}$ Madzhab Hanafi dikenal sebagai aliran fiqh yang paling liberal dalam kalangan Sunni, jika dibandingkan dengan madzhab Zhahiri, Hanbali, Maliki dan Syafieci. ${ }^{14}$

Post-Tradisionalisme Islam Post-Tradisionalisme Islam di Indonesia awalnya dirintis oleh Abdurrahman Wahid dengan gagasan

11 Keniscayaan fakta ini dapat dibaca dari banyak karya-karya intelektual muslim Indonesia maupun Barat: Fachry Ali \& Bachtiar Effendi, Merambah Jalan Baru Islam: Rekonstruksi Pemikiran Islam Indonesia Masa Orde Baru (1986); M.Syafiei Anwar, Pemikiran dan Aksi Islam Indonesia: Sebuah Kajian Politik tentang Cendekiawan Muslim Orde Baru (1995); Dedy Djamaluddin Malik \& Idi Subandi Ibrahim, Zaman Baru Islam Indonesia: Pemikiran dan Aksi Politik (1998); dan, Greg Barton, Gagasan Islam Liberal di Indonesia: Pemikiran Neo-Modernisme Nurcholish Madjid, Djohan Effendi, Ahmad Wahib dan Abdurrahman Wahid (1999)

12 Ibid.,

13 Jalaluddin Rakhmat, "Tinjauan Kritis atas Sejarah Fiqh: Dari Fiqh Al-Khulafa" Al-Rasyidin hingga Madzhab Liberalisme”, dalam Budhy Munawar Rachman (ad.), Kontekstualisasi Doktrin Islam dalam Sejarah, Jakarta, Paramadina, 1995, hal. 295-296.

14 Ali Yafie melukiskan 5 lapis lingkaran yang masing-masing diisi secara berurutan dari lingkaran terdalam sampai kepada yang terluar oleh 5 madzhab fiqh, yakni: madzhab Zhahiri, Hanbali, Maliki, Syafi" $i$ dan Hanafi. Lihat, ibid., hal. 294.
Pribumisasi Islam-nya (Islam Kultural). ${ }^{15}$ Tapi setelah Abdurrahman Wahid sempat menjadi presiden RI, citranya sebagai tokoh Islam Kultural jadi kurang signifikan. Sehingga selanjutnya tugas itu diwariskan pada generasi muda NU, khususnya Ulil Abshar Abdalla (Jaringan Islam Liberal / JIL). Proyek utama Post-Tradisonalisme Islam $^{16}$ adalah berusaha melakukan liberasi (pembebasan) pemahaman Islam di Indonesia melalui kritik di wilayah metodologi pemikiran Islam dan pencarian substansi Islam secara lebih mendalam. PostTradisionslisme ingin melakukan desakralisasi sumber-sumber khazanah Islam yang selama ini disakralkan. Pemikiran Post-Tradisionalisme banyak merujuk pada pemikiranpemikiran Nasr Hamid Abu Zaid (Mesir), Muhammed Arkoun (Al-Jazair), Muhammed Abed Al-Jabiri (Maroko), Hasan Hanafi (Mesir), Abdullah Ahmed An-Na ${ }^{e c i m}$ (Sudan), dan Fatimah Mernissi (Maroko). ${ }^{17}$

\section{Selisih Batas Pemikiran:}

Baik Neo-Modernisme maupun Post-Tradisionalisme memang mengusung agenda yang relatif sama dalam hal liberasi sosial, politik, ekonomi dan budaya. Bedanya adalah:

Post-Tradisionslisme ingin melakukan desakralisasi sumber-sumber khazanah Islam yang selama ini disakralkan, dan ini belum sempat dilakukan oleh Neo-Modernisme.

Selanjutnya, Neo-Modernisme Islam di Indonesia berkembang menjadi dua varian: Pro-Modernisasi (developmantalisme) dan Pro-Transformasi:

a. Tema yang diangkat oleh NeoModernisme Pro-Modernisasi adalah Sekulerisasi Politik (Cak-Nur); Reaktualisasi Ajaran Islam (Munawir Sadjali); dan Islam Rasional (Harun Nasution). ${ }^{18}$

b. Adapun tema yang diangkat oleh NeoModernisme Pro-Transformasi adalah Strategi Demokratisasi melalui Ranah

15 Hal ini diungkapkan oleh Zuhairi Misrawi, intelektual muda NU yang juga giat menyebarkan gagasan Post-Tradisionalisme, seperti dikutip oleh, Airlangga Pribadi (et.al.), op.cit., hal. 242.

\footnotetext{
16 Ibid., hal. 240-241.

17 Ibid., hal. 241-242.

18 Ibid., hal. 215
} 
Sosio-Kultural (Gus-Dur); Gagasan Ilmu Sosial Profetik (Kuntowijoyo); Teologi Sosial Transformatif (Dawam Rahardjo). ${ }^{19}$

\section{Isu Pokok Islam Liberal}

Charles Kurzman mengungkapka ${ }^{20}$ Islam Liberal adalah sebuah varian tradisi Islam yang melakukan perlawanan (oposisi) terhadap teokrasi, dukungan atas demokrasi, pembelaan hak-hak wanita, pembelaan hakhak minoritas, pembelaan terhadap kebebasan berfikir dan ide tentang kemajuan (idea of progress). Jadi, apa yang disebutkan Kurzman itu dapat disebut sebagai 6 isu (agenda) pokok Islam Liberal.

Keenam isu/agenda Islam Liberal itu diusung oleh kalangan muslim liberal di berbagai Negara dengan argumentasi yang beragam. Secara umum, Kurzman mengklasifikan jenis argumentasi yang diajukan kalangan muslim liberal di berbagai Negara itu menjadi 3 varian:

1. kelompok yang mengajukan Prinsip "Liberal Syarieeah": Syarieeah bersifat liberal pada dirinya sendiri jika dipahami secara tepat.

2. kelompok yang mengajukan Prinsip "Silent Syarieeah": Syarieeah tidak memberi jawaban jelas pada sebagian topik/masalah tertentu, sehingga manusia sendirilah yang menentukan aturan main dalam masalahmasalah tertentu.

3. kelompok yang mengajukan Prinsip "Interpreted-Syari"eah": Syari"eah harus ditengahi oleh penafsiran manusia untuk bisa diimplementasikan dalam kehidupan manusia. ${ }^{21}$

Dengan 3 argumentasi itu kalangan muslim liberal mengkonstruk pemikirannya. Maka 6 agenda Islam Liberal di atas masing-masing dibangun oleh 3 atau lebih argumentasi:

19 Ibid.

20 Periksa, Kurzman, Charles, Liberal Islam: A Sourcebook, New York, Oxford University Press, Inc., 1998, Terj. Bahrul Ulum \& Heri Junaidi, Jakarta, Paramadina, 2003, hal. xliii-lx

${ }^{21}$ Ibid., hal. xxxii - xlii

\begin{tabular}{|c|c|}
\hline $\begin{array}{c}\text { ISU/AGENDA ISLAM } \\
\text { LIBERAL }\end{array}$ & $\begin{array}{c}\text { VARIASI } \\
\text { ARGUMENTASI YANG } \\
\text { DIAJUKAN MUSLIM } \\
\text { LIBERAL } \\
\end{array}$ \\
\hline Againts Theocracy & $\begin{array}{l}\text { 1) Prinsip "silent syari"ah", } \\
\text { 2) Prinsip "politic is dirty", } \\
\text { 3) Prinsip "distorsi isu",, } \\
\text { dan 4) Prinsip "syari"ah is } \\
\text { path". }\end{array}$ \\
\hline Pro-Democracy & 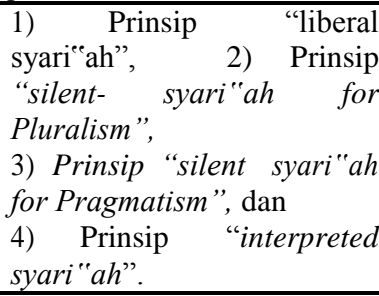 \\
\hline Rights of Women & $\begin{array}{l}\text { 1) Prinsip "liberal- } \\
\text { syari"ah", } \\
\text { 2) Prinsip "silent syari"ah", } \\
\text { 3) Prinsip "interpreted } \\
\text { syari"ah". }\end{array}$ \\
\hline Rights of Minority & $\begin{array}{l}\text { 1) Prinsip "liberal- } \\
\text { syari"ah", } \\
\text { 2) Prinsip "silent syari"ah", } \\
\text { dan } \\
\text { 3) Prinsip "interpreted } \\
\text { syari"ah". }\end{array}$ \\
\hline Freedom of Though & $\begin{array}{l}\text { 1) Prinsip "liberal- } \\
\text { syari"ah", } \\
\text { 2) Prinsip "silent syari"ah", } \\
\text { dan } \\
\text { 3) Prinsip "interpreted } \\
\text { syari"ah". }\end{array}$ \\
\hline Idea of Progress & $\begin{array}{l}\text { 1) Prinsip "liberal- } \\
\text { syari"ah", }\end{array}$ \\
\hline
\end{tabular}

\section{Rangka Fikir dan Metodologi Islam Liberal}

Bagian ini akan memaparkan secara singkat bagaimana rangka fakir seorang Muslim Liberal dalam memahami Islam. Dalam hal ini Ulil Abshar Abdalla menjadi sampelnya. ${ }^{22}$

\section{a. Titik Tolak: Islam adalah Agama yang \\ Benar}

Siapapun membutuh waktu beberapa saat hingga akhirnya bisa menerima Islam itu secara sukarela (secara intelektual), bukan secara terpaksa;

Islam adalah buku terbuka, setiap orang yang membacanya akan mungkin memahami dengan berbagai cara dan akan sampai pada

\footnotetext{
22 Silahkan periksa, Ulil Abshar Abdalla, op.cit., hal. 163-225
} 
sejumlah pengertian yang berbeda, kadang saling bertubrukan;

Kebebasan adalah dasar dan titik tolak agama, termasuk kebebasan dalam cara memahami Islam; ${ }^{23}$ atas landasan itulah muslim liberal memberikan tafsiran "lain" mengenai Islam.

\section{b. Kesempurnaan Islam dan Isolasionisme Teologi}

Menganggap kesempurnaan Islam sebagai agama yang mengatasi agama lain, me-naskh (membatalkan) agama-agama sebelumnya, dan memisahkan kebenaran Islam dengan kebenaran lainnya, sebenarnya adalah gejala isolasionisme teologis yang dilancarkan oleh tokoh-tokoh agama.

\section{c. Norma Universalitas Islam dan Hegemoni Barat}

Norma universalitas Islam seharusnya tidak perlu mengalami transformasi radikal menjadi sistem yang dipandang lengkap tetapi juga tertutup ketika harus menghadapi hegemoni "raksasa" Barat.

\section{d. Gradualisme dan Historisitas Wahyu serta Evolusi Islam}

Makna dari diturunkannya wahyu secara gradual (tanjim), selain berdampak penguatan psikologis bagi nabi dan sesuai pula dengan tradisi oral (bukan tradisi tulis) masyarakat Arab saat itu, adalah dimaksudkan sebagai respon atas peristiwa-peristiwa yang terjadi pada masyarakat Arab saat itu.

Sebagai respon, jelas sekali bahwa wahyu terkait dengan determinasi sosio-historis; maksudnya, ia dikondisikan, ditentukan, dibentuk, dicetak, dipengaruhi oleh kondisi sosio-hisoris di sekitarnya.

Karena terkait dengan determinasi historis, maka al-Qurean (meskipun tidak seluruhnya) menjadi bersifat historis. Munculnya ilmu asbab al-nuzul menjadi konfirmasi akan gejala tersebut.

\footnotetext{
${ }^{23}$ Dalam hal ini Ulil membantah pendapat ulama klasik yang menyatakan bahwa ayat "laa ikraha fi ad-diin" telah di-naskh (dibatalkan) oleh turunnya ayat-ayat qital (perang). Bantahan Ulil disandarkan pada tafsir Maulana Muhammad Ali, The Holy Qur"an, with English Translation and Commentary, Ohio, USA, Ahmadiyya Anjuman Isha "eat Islam Lahore Inc., 2002, hal. 116 , catatan kaki no. $256 a$
}

Karena al-Quran bersifat historis dan untuk sebagian tunduk pada determinasi historis, maka Islam pun memandang dirinya sebagai agama yang terus tumbuh, berubah dan dinamis (evolusi). Evolusi pemahaman Islam itu berlangsung terus menerus dengan dua determinasi, yaitu determinasi realitas (kenyataan sejarah) dan cita-cita (maqashid al-syari"ah). ${ }^{24}$

\section{e. Kenyataan Tanpa Batas, sementara Teks Terbatas}

Untuk menjembatani teks al-Qurean yang terbatas dengan kenyataan historis yang terus bergulir, diperlukan strategi penafsiran tertentu. Strategi penafsiran Nasr Hamid Abu Zayd dipandang bisa menjembatani teks yang terbatas dan kenyataan yang tak terbatas itu. Abu Zayd membuat skema segitiga berikut tentang proses pewahyuan: ${ }^{25}$

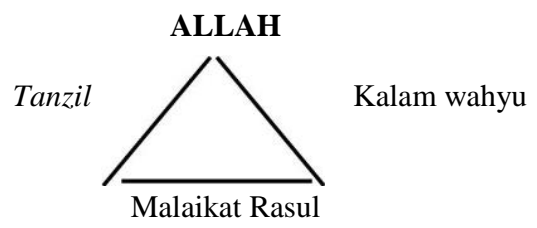

Skema segitiga itu memperlihatkan bahwa proses pewahyuan bukan hanya bersifat searah dari Allah via malaikat menuju kepada Rasul, tetapi melibatkan ketiga pihak sekaligus. Allah memang sumber wahyu, tetapi tidak "independen", karena melibatkan agen historis yang berada di luar-Nya. Allah adalah aksis dari cita-cita; Rasul adalah aksis dari kenyataan sejarah; dan malaikat adalah agensi yang mengantarai dua aksis itu.

Abu Zayd dengan skema itu ingin menunjukkan jadaliyyat al-,,alaqah bain al-nash wa al-waqi" (hubungan dialektis antara kenyataan dan nash); yang dengannya evolusi kebenaran Islam berlangsung secara dinamis dan terus berkembang.

Untuk mendukung konsep itu, digunakan pula konsep Al-Asymawy tentang "waqtiyyat

\footnotetext{
24 Pandangan ini disandarkan pada, Seyyed Hossein Nasr, Ideas and Realities of Islam, London, Unwin Hyman, 1988

${ }^{25}$ Ulil mengutip gambaran ini dari, Abu Zayd, Narh Hamid, Mafhum al-Nash: Dirasah fi „Ulum al-Qur"an, Tanpa Tempat, Al-Hay"ah al-Mishriyyah al-,Aammah li al-Kitab, 1993, hal. 47.
} 
al-ahkam" (temporalitas hukum-hukum yang terkandung di dalam nash). ${ }^{26}$

Perubahan ketentuan-ketentuan dan hukum dalam nash itu bukan sesuatu yang menjadi tujuan pada dirinya sendiri, tetapi perubahan menuju pada suatu cita-cita moral Islam, yakni: the embodiment of the fundamental human value of freedom and responsibility (perwujudan nilai kemanusiaan fundamental mengenai kebebasan dan tanggung jawab). ${ }^{27}$

\section{f. Cita-Cita Moral, Keterbatasan Historis dan Negosiasi}

Keberhasilan Islam di zaman Rasulullah saw. Sebagai agama yang efektif tidak bisa lain kecuali dengan masuk ke dalam tubuh kebudayaan Arab, memakai kekuatan-kekuatan dan materi sejarah yang bekerja dalam masyarakat Arab saat itu, meskipun resikonya Islam zaman Rasul juga diwarnai dan dipengaruhi oleh budaya Arab.

Jadi Islam zaman Rasul adalah produk negosiasi cita-cita moral Islam dan kenyataan sejarah dan budaya Arab saat itu. Sebagai suatu negosiasi, maka Islam pada zaman Rasul itu dipandang bukan satu-satunya "eksemplar" Islam yang mungkin di muka bumi ini. Itu adalah Islam diantara Islam yang lain.

\section{g. Nabi, Sahabat dan "Tajribah" Madinah}

Otoritas Muhammad sebagai nabi tidak pernah bisa diduplikasi oleh penguasapenguasa sesudahnya, karena otoritas itu bukan hanya bersifat keduniawian tetapi juga keakhiratan.

Otoritas para sahabat nabi sebagai khalifah bukan menggantikan Muhammad dalam kedudukannya sebagai nabi, tetapi menggantikan dalam kedudukannya sebagai pimpinan politik.

Tajribah (mencontoh pengalaman) Madinah pun tidak dapat dilakukan secara total, karena sebagai hasil negosiasi tentu Islam Madinah mengandung elemen-elemen yang khas Arab.

26 Al-Asymawi, Muhammad Said, Al-Islam AlSiyasi, Kairo, Sina li al-Nasyr, 1992, hal. 206.

${ }^{27}$ Rahman, Fazlur, loc.cit.
Islam dan Wahyu yang Terbuka Wahyu alQur'ean adalah samudera luas yang menjadi muara dari sejumlah tradisi yang telah ada sebelumnya. Undangan untuk berlayar ke tengah samudera dan menyelami kedalamnnya dipandang sebagai undangan untuk menyelami secara empatik tradisi-tradisi (agama) itu, dan tidak dipenjara oleh perbedaan-perbedaan lahiriah yang ada di "pantai" permukaannya.

\section{h. Menuju kepada Relativisme?}

Agama bukan semata-mata urusan fakta-fakta yang bisa diverifikasi secara empirik; tetapi soal makna dan pemaknaan. Jika fakta-fakta agama direkam dalam kitab suci, kebenaran bukan terletak pada teks kitab suci itu, tetapi pada pemaknaan atas teks itu. Jadi pemaknaan atas agama itu lebih penting. ${ }^{28}$

Islam Liberal pada akhirnya berkesimpulan, semua agama benar tapi tidak sama; semua agama benar bukan dalam pengertian eksklusif (menurut pemeluknya masingmasing), tetapi juga dalam arti lebih luas, yakni bila pemaknaan atas agama itu tepat pada situasi dan kondisi tertentu.

Suatu agama bisa saja mengkritik agama lain, tetapi bukan dalam rangka verifikasi fakta-fakta; kritik itu diarahkan pada pemaknaan yang tidak tepat atas agama dalam situasi dan tempat tertentu.

\section{Rethingking Islam Liberal}

Sejak awal, Leonard Binder, ${ }^{29}$ ilmuwan politik pertama yang mempopulerkan wacana Islam Liberal lewat buku hasil penelitiannya, mengungkapkan bahwa proyek penelitiannya ini dilakukan dengan dua tujuan. Pertama, untuk mengatasi "terisolirnya" penelitian lapangan, maka Ford Foundation memfasilitasi masing-masing peneliti dari berbagai negara (Iran, Mesir, Pakistan Maroko dan Indonesia) untuk datang ke Universitas Chicago dan turut serta dalam seminar antar bidang ilmu. Ke-dua, untuk mengantisipasi apa yang sering mengemuka di sepanjang

${ }^{28}$ Pada bagian ini Ulil mengutip dari Huston Smith: "religion is not primarily a matter of facts; it is a matter of meannings". Lihat, Smith, Huston, The World "s Religion, New-York, HarperCollins Publisher, 1991, hal. 9 .

29 Binder (a), ibid., 
jalannya "Kebangkitan Islam", proyek ini berupaya menemukan alternatif paradigma, selain dari paradigma yang sudah ada, yakni meningkatnya perubahan sosial dapat mengendurkan komitmen keagamaan Islam. Artinya, proyek ini bermaksud mengajukan paradigma: perubahan sosial tidak harus mengendurkan komitmen keagamaan Islam.

Dari tujuan pertamanya, tampak ada suatu kebutuhan dari Binder dan Ford Foundation untuk tidak membiarkan para peneliti dunia Islam "terisolir" dari Chicago. Pertama, karena Binder adalah ilmuwan politik; coba tebak apa yang paling memenuhi fikirannya selain politik? Memang, Fazlur Rahman yang pemikir Islam itu dilibatkan sejak awal. Tapi mengapa Fazlur Rahman "tiba-tiba" hilang

ketika hasil penelitian itu dibukukan? ${ }^{30}$ Analisis ini rupanya ada hubungan dengan analisis berikutnya.

Kedua, Binder sendiri menuliskan, "Dengan melibatkan diri dalam wacana rasional bersama mereka yang kesadarannya telah dibentuk oleh budaya Islam, upaya peningkatan prospek liberalisme politik di kawasan itu dan kawasan lain yang belum akrab dengan wacana ini bukanlah suatu yang mustahil". ${ }^{31}$ Jadi jelaslah, Binder ingin mengembangkan liberalisme politik di Dunia Islam dengan cara me-liberasi pemahaman umat Islam atas agamanya melalui "pembangunan opini" dari para peneliti Dunia Islam yang dikumpulkan di Chicago itu, agar tidak "terisolir", katanya.

Dari tujuannya yang ke-dua, Binder ingin mengembangkan opini bahwa, perubahan sosial tidak akan mengendurkan komitmen keagamaan Islam. Kalau yang dimaksud Binder dengan perubahan sosial itu indikatornya adalah akses atas modernisasi

30 Maksudnya, buku Binder, "Islamic Liberalism" hasil penelitian yang dikerjakannya bersama Fazlur Rahman, tidak melibatkan nama Fazlur Rahman sebagai penulisnya? Ada apa Binder dengan Rahman? Sampaisampai pada Pengantar buku itu Binder harus terkesan "menghibur" Rahman dengan kalimat: "Kepada Fazlur Rahman juga kami sampaikan beribu terima kasih atas persahabatan yang tetap utuh". Baca, ibid., hlm. vi. "tetap utuh"!?

31 Ibid., hal. 2 dan teknologi, dari dulu juga mereka yang berpikir modern dan mampu mengakses teknologi tidak kalah komitmen keagamaannya. Setidaknya di Indonesia, kita saksinya.

Jadi, tidak benar bahwa perubahan sosial itu selalu bikin orang jadi sekuler. Lain hal kalau yang dimaksud Binder dengan perubahan sosial itu adalah liberalisasi moral atau agama!

\section{a. Meninjau Rangka Fikir Islam Liberal}

Islam Liberal memandang al-Qur'an bersifat historis (sebagai respon dari situasi dan kondisi sejarah saat turunnya dulu) dan tunduk pada determinasi historis. Bagaimana mungkin dapat dikatakan demikian, sedangkan tidak setiap ayat di dalam al-Qur"ean memiliki catatan asbab an-nuzul-nya. Apakah Islam Liberal akan menerima sebagian ayat yang memiliki catatan asbab al-nuzul-nya saja dengan menolak sebagian yang lain? Katakanlah seluruh ayat-ayat al-Qur'an memiliki asbab an-nuzul tetapi tidak seluruhnya terekam dalam teks sejarah, seperti yang diklaim oleh muslim liberal. Bukankah klaim yang tidak bersandar pada bukti ilmiah merupakan "pemerkosaan" kebenaran? Inilah kerancuan pertama yang ditemui dari metode penafsiran al-Qur"ean versi Islam Liberal.

Cita-cita Sosial Islam yang menjadi acuan determinasi dari proses evolusi pemahaman agama yang berkembang terus menurut Islam Liberal adalah: the embodiment of the fundamental human value of freedom and responsibility (perwujudan nilai kemanusiaan fundamental mengenai kebebasan dan tanggung jawab). Masalah yang muncul adalah sampai garis mana ambang batas kebebasan dan tanggung jawab itu dapat menjadi acuan cita-cita sosial Islam; dan siapa yang berhak mengklaim bahwa pengetahuannya tentang ambang batas kebebasan dan tanggung jawab itu benar dan sah sebagai acuan hidup bermasyarakat? Jika hanya untuk acuan hidup seorang diri boleh saja. Masalahnya, manusia hidup bermasyarakat. Jika tidak ada ambang batas yang jelas berlaku kolektif untuk suatu masyarakat, maka kebebasan seseorang akan tabrakan dengan kebebasan orang lain. Di sinilah kiranya 
kalangan Islam Liberal patut menyadari pentingnya suatu wadah berskala nasional untuk merumuskan bersama cita-cita sosial Islam tersebut. Jika demikian, muslim liberal tidak bisa tidak harus mengakui pentingnya kehadiran institusi formal Islam yang memiliki otoritas nasional.

Bagi Islam Liberal, salah/benar dalam agama bukanlah soal teks kitab suci atau fakta empirik, tetapi soal apakah pemaknaan atas agama itu tepat dalam konteks situasi dan kondisi historis saat ini. Masalahnya, apa ukuran dari tepat atau tidaknya pemaknaan seseorang atas agama pada situasi dan kondisi tertentu? Jawaban dari pertanyaan itu pasti sulit untuk diterima sebagai pendapat bersama, karena setiap orang punya pemaknaan yang berbeda atas agamanya. Sampailah Islam Liberal pada pluralisme yang secara individual tampak mewah, tetapi secara sosial bisa destruktif.

Hal lain yang menjadi acuan determinasi dari proses evolusi pemahaman agama yang berkembang terus bagi Islam Liberal adalah kenyataan sejarah yang kita hadapi. Jadi pemahaman Islam yang benar bagi Islam Liberal adalah hasil negosiasi antara cita-cita sosial Islam dan kenyataan sejarah saat ini. Masalahnya, siapa orang yang berhak mengklaim bahwa pengamatannya akan kenyataan sejarah tentang situasi dan kondisi kekinian itu benar, sehingga dianggap sah sebagai acuan determinasi yang akan dinegosiasikan dengan cita-cita sosial Islam untuk menghasilkan pemahaman agama yang benar? Kekeliruan membaca kenyataan situasi dan kondisi sejarah kekinian akan membawa orang berpikir salah dan menyikapi situasi secara salah. Hal ini akan terbayang jelas ketika kita berani menakar akurasi isu/agenda Islam Liberal dalam konteks ke-Indonesia-an.

Islam Liberal seperti yang dipahami Ulil Abshar Abdalla, mengakui bahwa penafsiran al-Qur"an menurutnya mengandung kecenderungan di satu pihak bersikap "selektif" terhadap ayat-ayat al-Qur"an, dan di pihak lain "tabriri" (melegitimasikan) terhadap gagasan eksternal yang ada pada penafsir. Baginya hal itu wajar, sebagai peleburan cakrawala antara gagasan al-
Qur'an dan gagasan mufassir. ${ }^{32}$ Ini suatu sikap inkonsistensi dari sikap semula yang mengatakan bahwa, pemahaman agama yang benar itu hanya ditentukan oleh dua determinasi, yakni determinasi cita-cita sosial Islam dan kenyataan sejarah saja. Tapi kemudian dimasukkan gagasan eksternal mufassir sebagai acuan determinasi ke-tiga, sehingga timbul kesan pemaksaan kehendak mufassir ketika memahami alQur'an.

\section{Menakar Isu (Agenda) Islam Liberal dalam Konteks ke-Indonesiaan Kini}

Seperti kata Huston Smith yang di-amini Ulil Abshar Abdalla, salah/benar dalam agama bukanlah soal teks kitab suci atau fakta empiric, tetapi soal apakah pemaknaan atas agama itu tepat dalam konteks situasi dan kondisi historis saat ini. Karena itu, siapa pun bisa menguji akurasi kontekstualitas 6 isu pokok yang diusung oleh Islam Liberal dalam merespons tuntutan situasi dan kondisi di Indonesia saat ini.

\section{1) Againts Theocracy}

Penulis sepakat dengan argumentasi pertama Islam Liberal, "silent syarieeah" dalam hal teokrasi. Adalah benar bahwa al-Quran dan Sunnah tidak mengatur bentuk pemerintahan pada masyarakat muslim harus teokrasi. Khusus konteks di Indonesia, setelah reformasi Mei 1998 perubahan iklim sosial dan politik memang sangat cepat. Desakan perubahan yang diteriakan oleh ekstrim kanan maupun ekstrim kiri sama-sama memperoleh "momentum emas" untuk merubah wajah Indonesia. Ekses negatif sebagai sosial-cost dari proses belajar berdemokrasi selalu saja ada dalam bentuk konflik baik vertikal maupun horizontal. Untungnya, Pemilu 1999 bisa terlaksana.

Desakan reformasi telah mendesak keluarnya berbagai peraturan dan UU baru. Pada tahun 1999 telah keluar UU No. 22 /Th. 1999 tentang Otonomi Daerah. UU ini membawa angin segar bagi seluruh anak bangsa karena berimbas pada desentralisasi pemerintahan dari pusat ke daerah, yang artinya orang

\footnotetext{
${ }^{32}$ Ulil Abshar Abdalla, op.cit., hal. 179, catatan kaki No. 9.
} 
daerah kini punya ruang lebih bebas untuk mengatur "rumah-tangganya" sendiri. Hal ini berdampak pada perubahan banyak aspek kehidupan masyarakat, termasuk pada aspek agama. Di Jawa Barat saja, sejak tahun 2000 telah ada 3 Kabupaten yang mengeluarkan Perda yang mengacu Syariecat Islam, yaitu: Kab. Garut dengan Perda No. 6 / Th. 2000 tentang Pelanggaran Kesusilaan; Kab. Tasikmalaya dengan Perda No. 1 / Th. 2000 tentang Pemberantasan Pelacuran; dan Kab. Cianjur dengan Perda No. 21 / Th. 2000 tentang Larangan Pelacuran. Selanjutnya, D.I. Aceh diberikan Otonomi Khusus dengan keluarnya UU No. 18 / 2001, sehingga kini bernama Nangroe Aceh Darussalam. Selain kasus Aceh yang sejak Orde Baru memang sarat konflik, apakah fenomena pemberlakuan syarieat Islam di Indonesia kini merusak demokrasi? Rasanya tidak, karena ia tidak datang secara trickle-down dari pemerintah pusat, tetapi datang secara bottom-up dari desakan masyarakat di daerah-daerah. Alihalih merusak demokrasi, justru penguatan resistensi publik dan bargaining position rakyat daerah di hadapan pemerintah pusat.

\section{2) Pro-Democracy}

Penulis setuju sepenuhnya dengan demokrasi. Karena demokrasi adalah satusatunya sistem yang dapat mengoreksi dirinya sendiri. Ini penting karena setiap manusia punya "sisi-gelap". Konteks Indonesia pasca reformasi 1998, angin demokrasi bertiup cukup kencang, bahkan cendrung menjadi "angin puting-beliung". Jika orang tidak didukung dengan supra struktur intelektual dan kematangan moralitas yang mapan, demokrasi bisa jadi democrazy, Man!

\section{3) Rigths of Women}

Di satu sisi, di Indonesia memang masih banyak kekerasan terhadap perempuan. Namun pada sisi lain, di Indonesia juga kursi presiden sudah bisa diduduki oleh perempuan. AS yang mengaku sebagai "guru"nya demokrasi saja belum punya presiden perempuan. Yang jelas perempuan adalah manusia yang sama mulianya dengan pria. Perempuan nggak boleh jadi warga negara kelas II. Islam sangat memuliakan perempuan (Prinsip "Liberal Syari"ah"). Dan orang Indonesia ternyata tidak buruk mengamalkan prinsip itu. Setidaknya dibanding orang Amerika.

\section{4) Freedom of Though}

Kebebasan berpikir di Indonesia sejak bergulirnya reformasi Mei 1998 sudah bagus. Dari ekstrem kiri sampai ekstrem kanan bisa teriak dan bikin partai tanpa dicekal oleh pemerintah. Kalau ada kasus seperti yang dialami Partai Pembebasan Nasional bentrok dengan FPI, sekali lagi, itulah social-cost dari proses belajar demokrasi yang belum tuntas. Yang jelas, di Indonesia belum ada orang yang bernasib seperti Galileo Galilei, yang harus dibunuh karena berbeda faham dengan penguasa otoritas agama. Ulil Abshar Abdalla dengan JIL-nya yang kontroversial itu masih dapat terus menghirup udara bebas di luar sana. Satu indikasi, ,umara dan ,ulama di Indonesia terbilang cukup demokratis mengolah freedom of though di Indonesia.

\section{5) Idea of Progress}

PerkembanganpemikiranIslamdi

Indonesia dalam merespon modernisasi terbilang sudah cukup progresif. Sejak 1970an, Cak-Nur, Gus-Dur, Djohan Effendi dan Ahmad Wahib telah cukup membuat Greg Barton bisa "tersenyum" sambil mencatat wacana Neo-Modernisme mereka dalam bukunya. $^{33}$ Masalahnya, ketika idea of progress sudah berjalan bagus, mengapa Indonesia sejak 1997 sampai sekarang belum juga mampu bangkit sepenuhnya dari krisis? Mungkin kita membutuhkan lebih dari sekedar idea of progress. Spirituality and action, misalnya.

\section{6) Rights of Minority}

Bicara minoritas-mayoritas di Indonesia ini unik. Alat ukur apa yang mau kita gunakan? Agama, ekonomi, budaya, atau politik? Yang mayoritas agama (muslim), justru minoritas ekonomi dan politik. Yang mayoritas ekonomi (konglomerat pribumi dan etnis China), justru minoritas agama, budaya dan politik. Yang mayoritas budaya, justru minoritas ekonomi. Jika yang dimaksud adalah minoritas agama, dalam konteks di Indonesia kini mereka adalah mayoritas ekonomi dan politik. Silahkan periksa mall-mall di kota-kota besar, tanya

\footnotetext{
${ }^{33}$ Barton, Greg, loc.cit.,
} 
siapa yang punya? Coba ingat-ingat siapa yang selalu atau paling sering menang Pemilu dalam kancah politik Indonesia, parpol Islam atau parpol sekular?

Yang harus diingat, Islam Liberal sebagaimana dipublikasikan Binder, adalah wacana Islam yang melancarkan liberasi, kritik dan perlawanan terhadap ideologi developmantalisme (pembangunan) yang dijalankan oleh penguasa. Artinya, minoritas yang dibela oleh Islam Liberal seharusnya adalah minoritas politik, bukan minoritas agama. Di negara-negara Timur Tengah yang intensitas dan frekuensi formalisasi syarie at Islamnya lebih mendominasi kehidupan politik negara, kenyataan bahwa penguasa itu berideologi Islam tampak sangat jelas. Artinya, di sana proses liberasi agama akan searah dengan liberasi politik. Dengan begitu, jika terjadi liberasi pemikiran Islam di Timur Tengah, implikasinya pasti berpengaruh pada liberasi politik di sana. Tapi bagaimana di Indonesia, yang mayoritas agamanya tidak bermakna sama dan sebangun dengan mayoritas politik? Liberasi Islam di Indonesia bukan gerakan "kiri" (perlawanan atas status-quo mayoritas politik), justru malah gerakan "kanan" yang mengukuhkan hegemoni mayoritas politik nasionalis sekuler di Indonesia.

\section{SIMPULAN}

Islam Liberal adalah buah kreativitas pemikir muslim kontemporer yang layak diapresiasi. Orang tidak bisa dihakimi oleh siapapun karena pemikirannya. Tapi orang akan dihakimi oleh lingkungan sosialnya ketika aksinya tidak menempati ruang dan waktu yang tepat. Jika aksi adalah produk pemikiran, maka pemikiran yang kontra produktif bagi kebutuhan konteks ruang dan waktunya pun akan dihakimi oleh opini publik. Inilah logika demokrasi. Demikian pula halnya Islam Liberal. Karena konteks ruang dan waktu yang berbeda, khususnya dalam hal hubungan real politic dan real religious, maka tidak aneh jika Islam Liberal menjadi "kiri" di Timur Tengah, tetapi menjadi "kanan" di Indonesia. Di Timur Tengah ia berhadapan dengan penguasa yang "berjubah agama", namun di Indonesia ia berhadapan dengan rakyat yang mayoritas muslim.

\section{DAFTAR PUSTAKA}

Abu Zayd, Nasr Hamid, Mafhum al-Nash: Dirasah fi ,Ulum al-Qur"an (tt: AlHay $^{\text {ee }}$ ah al-Mishriyyah al-,,Aammah li alKitab, 1993.

Al-Asymawi, Muhammad Said, Al-Islam AlSiyasi,Kairo, Sina li al-Nasyr, 1992.

Ali, Fachry \& Bachtiar Effendi, Merambah Jalan Baru Islam: Rekonstruksi Pemikiran Islam Indonesia Masa Orde Baru, Bandung, Mizan, 1986.

Ali, Maulana Muhammad, The Holy Qur"an, with English Translation and Commentary, Ohio, USA, Ahmadiyya Anjuman Ishae'at Islam Lahore Inc.: 2002.

Anwar, M. Syafiei, Pemikiran dan Aksi Islam Indonesia: Sebuah Kajian Politik tentang Cendekiawan Muslim Orde Baru, Jakarta, Paramadina, 1995.

Abdalla, Ulil Abshar, Menyegarkan Kembali Pemikiran Islam: Bunga Rampai SuratSurat Tersiar,Jakarta, Nalar, 2007.

Abdalla, Ulil Abshar, Menyegarkan Kembali Pemahaman Islam, Harian Kompas, Senin 18 November 2002.

Assyaukanie, Luthfi, (ed.), Wajah Liberal Islam Indonesia, Jakarta, Teater Utan Kayu JIL 2002.

Barton, Greg, Gagasan Islam Liberal di Indonesia: Pemikiran Neo-Modernisme Nurcholish Madjid, Djohan Effendi, Ahmad Wahib dan Abdurrahman Wahid, Jakarta, Paramadina, 1999.

Binder, Leonard, Islamic Liberalism, Universitas of Chicago Press, 1988.

Binder, Leonard, Islamic Liberalism, Terj. Imam Muttaqin, Yogyakarta, Pustaka Pelajar, 2001.

Kurzman, Charles, Liberal Islam: A Sourcebook, Terj. Bahrul Ulum \& Heri Junaidi, Jakarta, Paramadina, 2003.

Malik, Dedy Djamaluddin \& Idi Subandi Ibrahim, Zaman Baru Islam Indonesia: Pemikiran dan Aksi Politik, Bandung, Zaman Wacana Mulya, 1998. 
Nasr, Seyyed Hossein, Ideas and Realities of Islam, London, Unwin Hyman, 1988.

Pribadi, Airlangga, \& M. Yudhie R. Haryono, Post Islam Liberal, Bekasi, Gugus Press, 2002.

Rahman, Fazlur, Islam, Chicago \& London, The University of Chicago Press, 1979.

Rakhmat, Jalaluddin, "Tinjauan Kritis atas Sejarah Fiqh: Dari Fiqh Al-Khulafa" AlRasyidin hingga Madzhab Liberalisme", dalam Budhy Munawar Rachman (ad.), Kontekstualisasi Doktrin Islam dalam Sejarah, Jakarta, Paramadina, 1995.

Smith, Huston, The World"s Religion, NewYork, HarperCollins Publisher, 1991.

Kuntowijoyo, Islam Sebagai Ilmu: Epistemologi, Metodologi dan Etika, Yogyakarta, Tiara Wacana, 2006.

Lane, Michael, Introduction to Structuralism, New York, Basic-Books Inc., 1970.

Madjid, Nurcholish, Islam Kemodernan dan Keindonesiaan, Bandung, Mizan, 1987.
Madjid, Nurcholish, Masalah Teknologi dan Kemungkinan Pertimbangan Keimanan Islam dalam Ikutserta Mengatasi Ekses Negatif Penggunaannya, makalah KKA Paramadina, No.31/Th.III/ 1989.

Malik, Dedy Djamaluddin \& Idi Subandy Ibrahim, Zaman Baru Islam Indonesia: Pemikiran dan Aksi Politik Abdurrahman Wahid, M.Amien Rais, Nurcholish Madjid \& Jalaluddin Rakhmat, Bandung, Zaman Wacana Mulia, 1998.

Rahman, Fazlur, Islamisasi Ilmu: Sebuah Respons, dalam, Jurnal Ilmu dan Kebudayaan ULUMUL QUR ${ }^{e} A N$, Vol. III No.4 Th. 1992.

Root, Michael, Philisophy of Sosial Science, Oxford, Blackwell, 1993.

Subhan, Arief, Dr. Kuntowijoyo: al-Qur"an sebagai Paradigma, dalam Jurnal Ilmu dan Kebudayaan ULUMUL QUR"AN, No. 4, Vol. V, Th. 1994. 